\title{
DISCUSSION
}

\section{Physical characteristics of subglacial tills}

\author{
B. G. CLARKE, D. B. HUGHES and S. HASHEMI (2008). Geotechnique 58, No. 1, pp. 67-76
}

\begin{abstract}
A. D. W. Sparks, University of Cape Town, South Africa
\end{abstract} The paper by the authors Clarke, Hughes and Hashemi is an important contribution to the science of soil mechanics and is based on 5500 samples. It is interesting that both clays and silts have been part of the same database in this study. The authors have also sought to distinguish between characteristic values that can be used in design, and the 'baseline values' to be used to limit claims in future contracts.

It seems that guides for future contracts will be based on the values of soil shear strength derived from the Atterberg index values.

The writers have developed three different models that use the liquid limit and the present water content of the clay to predict the shear strength of the clay (see below). All three models produce excellent agreement with the average strengths as found by the authors for the three clays in their Table 1.

There exists, however, one 'hidden time-bomb' within this approach. This is the heavily precompressed clay.

Samples of the same soil can all have identical Atterberg limits, but these samples can be either 'normally consolidated' or they may be 'precompressed', or 'heavily precompressed'. Predictions of the undrained strength of saturated precompressed or normally consolidated clays by using Atterberg limits are acceptable. Predictions based on water content before shear are also conservative (on the safe side) if made for normally consolidated clays subjected to slow drained shear. A heavily precompressed clay will, however, swell during drained shear and absorb water. This reduces the shear strength of the clay. Even if we enter our formulae with the actual 'water content at failure', this may give only an upper limit for predicting the drained shear strength of a precompressed clay. The predicted shear strength from Atterberg limits for heavily precompressed clays should, however, also be reduced further.

A heavily precompressed clay contains shiny slickensided potential shear surfaces caused by the precompression. The writer believes that these slickensides cause an extra reduction in the drained shear strength of precompressed clays apart from the reduction owing to an increase in water content. This extra reduction for precompressed clays has been noted in Fig. 4.5 by Lee \& Inglis (1968), which is based on results by Henkel.

In field constructions such as cuttings in existing slopes in precompressed clays it is likely that the shear strength of the soil will decrease with time along any potential slip surface. Vane tests tend to record peak shear stresses of sensitive clays, and should also be used to measure the remoulded strength. In nature the whole slip surface does not reach the peak strength simultaneously, because various portions of a slip surface may have already passed the peak strength. For heavily precompressed clays, even the vane remoulded strength value should be reduced further because the saturated clay in the field will continue to increase its water content over the years.

A mathematical model for predicting the shear strength of a clay from its liquid limit and current water content cannot be used as a substitute for field and laboratory shear tests; it can, however, be used to check the possible validity of actual shear tests.

\section{The first model, for saturated remoulded clays}

The first model was derived by the writer for investigating the suction pore pressures in saturated clays in arid regions (Sparks, 1999). An equation was given in the 1999 paper for estimating the average effective pressure $p_{0}^{\prime}(\mathrm{kPa})=\left(\sigma_{1}^{\prime}+\right.$ $\left.\sigma_{2}^{\prime}+\sigma_{3}^{\prime}\right) / 3$ in terms of the water content and the liquid limit values.

The undrained shear strength $s_{\mathrm{u}}$ of remoulded clays was calculated from the average effective pressure $p_{0}^{\prime}(\mathrm{kPa})$ by using a multiplier $\left\{m\right.$. $\left.\sin \left(\varphi^{\prime}\right)\right\}$ in the equation

$$
\begin{aligned}
& s_{\mathrm{u}}(\mathrm{kPa})=m p_{0}^{\prime} \cdot \sin \left(\varphi^{\prime}\right) \\
& \text { where } m=0 \cdot 6 \text { (approx. for remoulded clays) }
\end{aligned}
$$

and

$$
\varphi^{\prime}=35^{\circ}-17^{\circ} \cdot \log (\mathrm{LL} \% / 20)
$$

This method provided good predictions of the undrained shear strength if LL\% was less than $70 \%$; this method, however, needs modification.

\section{Second model}

Instead of using $m=0 \cdot 6$, the writer used the formula

$$
m=0.5+0 \cdot 0027 . \operatorname{LL}(\%)
$$

This model also provides excellent agreement with the mean values published by the three authors in their Table 1 .

Third model (e.g. for undrained tests, normally consolidated clays)

The writer prefers the third model that is described by equations (12) below. These equations are for estimating $s_{\mathrm{u}}$ directly by using LL\% and the water content $\mathrm{w} \%$.

$$
\begin{aligned}
& N=(8 \cdot 317 \mathrm{LL} \%-83 \cdot 17) \\
& D=\left(1 \cdot 117 \mathrm{LL} \%+w_{\mathrm{c}} \%-21 \cdot 03\right) \\
& \log _{10} s_{\mathrm{u}}(\mathrm{kPa})=(N / D-3 \cdot 928)
\end{aligned}
$$

Hence the predicted value $s_{\mathrm{u}}$ is known. Fig. 16 is based on equations (12).

Beware, if the soil is heavily precompressed, because its drained strength might be as low as one-third of the predicted value from equation 12(c).

Equation $12(\mathrm{c})$ can be used for undrained tests. Equations (12) should underestimate the drained strength of normally consolidated clays if the water content prior to shearing is used in equation (12b). Equations (12) will provide a close prediction of the drained strength of normally consolidated clays if the water content at failure is used in equation (12b).

Excellent agreement occurs between the mean values 


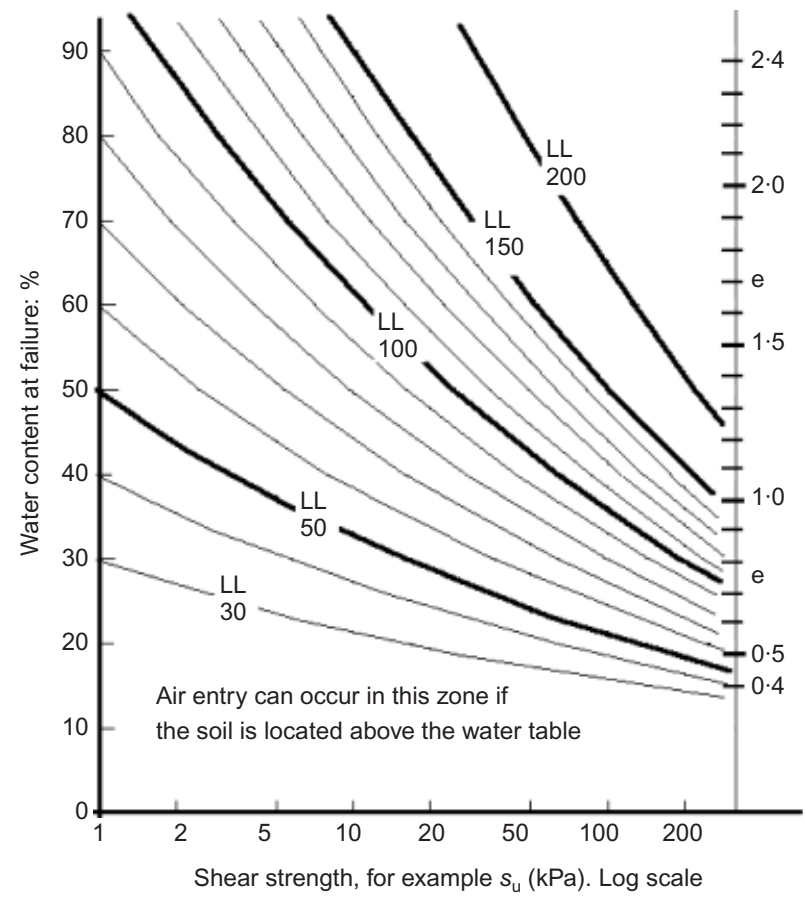

Fig. 16. Shear strength plotted against water content from equations (12). Originally derived from undrained strength of remoulded, saturated clay. Useful for other modes of testing. Note: drained strength of highly precompressed clays can be as low as one third of the above strength

shown by the authors in Table 1 of their paper, and the strength values predicted by equations (12), see Fig. 17.

Equations (5) satisfy the Burland rules described by the present author; and equations (5) also satisfy most of the shear strength data given by Skempton \& Bishop (1954).

\section{Predicting the critical void ratio curves}

The critical state curve for each liquid limit can be plotted on a diagram of water content versus the value of $p_{0}^{\prime}$. The critical state curve for each type of clay (as determined by the liquid limit) can be estimated by using the following equation

$$
p_{\text {critical }}^{\prime}=s_{\mathrm{u}}(2 / M)
$$

where $s_{\mathrm{u}}$ is determined in equation (5(c)) for LL and $w_{\mathrm{c}}$ and

$$
M=\left(6 \sin \varphi^{\prime}\right) /\left(3-\sin \varphi^{\prime}\right)
$$

where

$$
\varphi^{\prime}=35^{\circ}-17^{\circ} \cdot \log (\mathrm{LL} \% / 20)
$$

If the present in situ value of $p_{0}^{\prime}(\mathrm{kPa})=\left(\sigma_{1}^{\prime}+\sigma_{2}^{\prime}+\sigma_{3}^{\prime}\right) / 3$ is less than $p_{\text {critical }}^{\prime}$, then the clay is on the 'dry side' of the critical curve. Saturated samples on the 'dry side' are precompressed and will expand during drained shear. It is essential to identify the in situ soils that will expand and absorb water during drained shear, as it is these soils which will lose shear strength with time.

\section{CONCLUSION}

In conclusion the writer supports the use of methods that predict the shear strength of clays by using Atterberg index properties, providing these models are not used as a substitute for necessary shear strength tests.

It is necessary to identify precompressed clays by following the guidelines outlined below. (a) Use consolidometer tests

(b) Use'undrained' isotropic tests in which the cell pressure is varied while the sample is connected via a stop cock to a water reservoir. For a short interval, drainage is allowed to see whether the sample expands or contracts. When zero drainage occurs, the cell pressure provides the in situ value of $p^{\prime}$ for the sample. This can then be compared with the answer from equation (6) above. If the in situ value of $p^{\prime}$ is less than $p_{\text {critical }}^{\prime}$ then the soil will swell and weaken in the field when subjected to slow drained shear.

(c) One should conduct a drained shear test on the sample using the in situ value of $p^{\prime}$ as the cell pressure. This will provide the actual strength of the soil and the water content at failure. Enter this water content at failure into equations (12) to find a value of a theoretical strength $s_{\mathrm{u}}$ which will be above the actual drained shear strength of the soil. The difference between the two will indicate the extra reduction in shear strength owing to realignment of clay particles along slickensides and so on.

(d) One can draw rebound curves at a slope of $C$ s on a plot of $p^{\prime}$ plotted against $w_{\mathrm{c}}$ to determine the preconsolidation pressure.

(e) Field observations are also necessary. For example if the water content at a depth of $5 \mathrm{~m}$ is less than the plastic limit, then suspect a precompressed clay. If the soil is slickensided (shiny slip planes) then suspect a heavily precompressed clay.

The design strength used for a heavily precompressed clay should be about one-third of the value given by equation 5(c) above.

\section{Authors' reply}

The comments from Professor Sparks are most welcome. There are numerous empirical correlations between physical and mechanical characteristics of soils as the authors have highlighted in their paper but their use is often site specific and should be treated with caution. One reason that the correlations are site specific is because undrained shear strength is not just a function of water content and Atterberg limits. It is therefore interesting to note that the empirical relationships that Professor Sparks developed between undrained shear strength and physical characteristics of clays also apply to the glacial tills described in this paper.

A design engineer faced with typical results from a ground investigation in glacial till has a difficult choice to make in selecting the characteristic design values because of the spatial variability of the till and the impact that has upon the test results. Hence a framework is helpful in assessing the quality of the data and as a guide to the selection of preliminary design values. Professor Sparks' proposal needs to be investigated further because it may provide a more robust relationship between undrained shear strength and the Atterberg limits and water content for glacial tills. It must be noted, however, that the values quoted in Table 1 are the statistical mean and upper and lower quartile values for the chosen parameter. Thus an undrained shear strength of $125 \mathrm{kPa}$ (Fig. 16) represents the upper quartile value of shear strength (see Table 1 of the paper); the water content of $23.7 \%$ is not the water content of sample of glacial till with a strength of $125 \mathrm{kPa}$ but is the upper quartile value of the water content. In practice there is no simple correlation between water content and shear strength for these glacial tills.

Professor Sparks makes a very valuable observation on the potential shear surfaces generated during 'heavy precompression'. These are observed in subglacial tills and have 


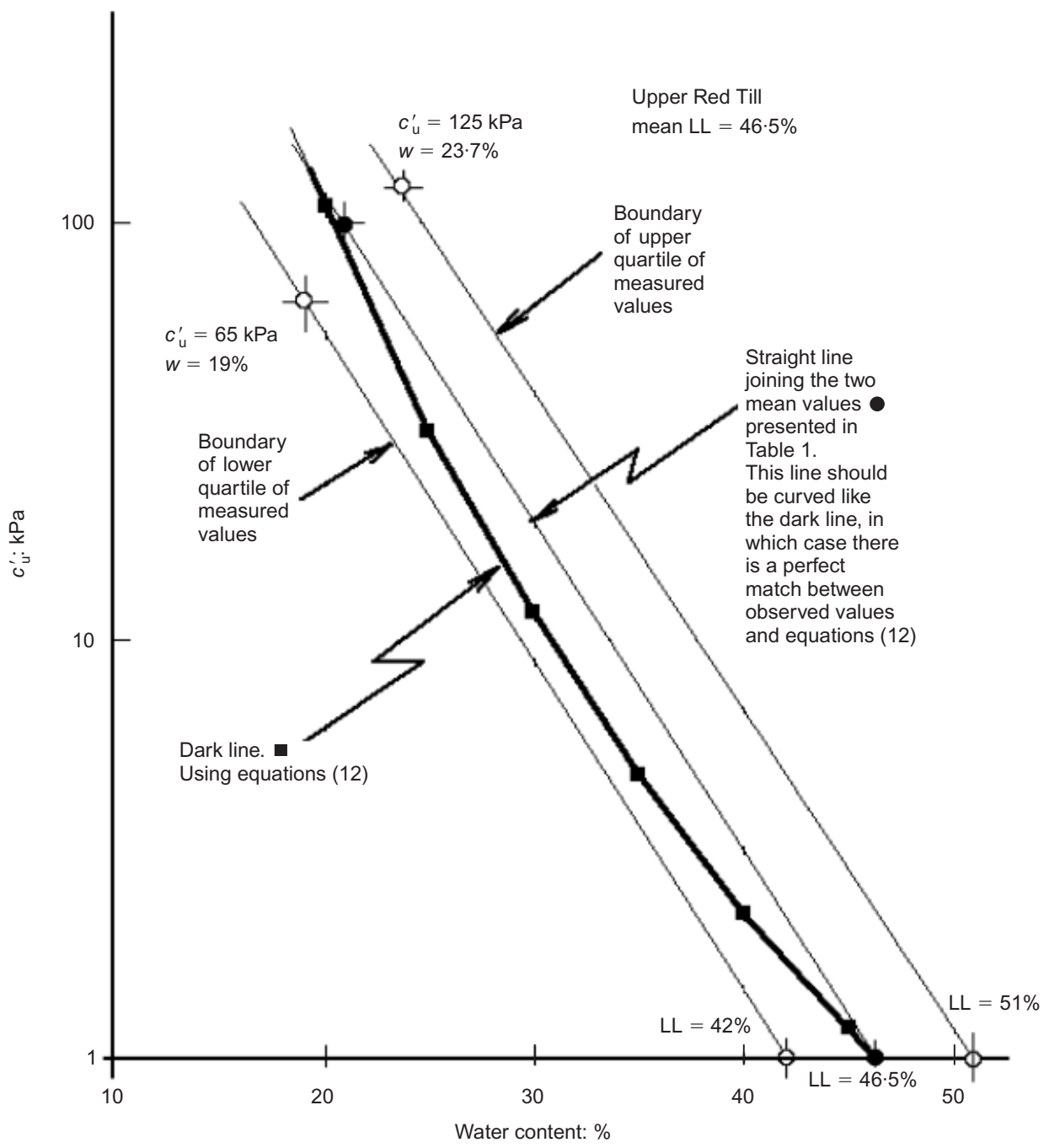

Fig. 17. Upper Red Till. The same perfect fit exists between the observed valued for the Lower Red Till and the Lower Grey Till, and the values from equations (5)

been associated with the history of deposition. These shear surfaces can contribute to the spatial variability of the till and, in some cases, lead to a weak zone within a glacial till, which could lead to failure.

This paper refers to the physical characteristics of the tills using undrained shear strength as a means of classifying the tills. Undrained shear strength is also used as a design parameter; hence the paper does describe a framework for selecting appropriate characteristic design values. Professor Sparks refers to the drained strength of clay which, according to equation 12 (c), is the maximum shear stress at failure if the test is slow enough to allow water to flow from intact clay to the failure surface. It is not usual in routine ground investigations to measure water content on a failure surface generated in an undrained triaxial test. The water content, however, used in the statistical analysis in the paper is the water content of the whole sample. Undrained failure is typically achieved within $10 \mathrm{~min}$ of applying a deviator stress and in that time it is unlikely that the water content profile within a sample changes because of the low permeability of the till. It is possible that the water content on the failure surface is higher than the average water content of the sample because of the spatial variability of water content in glacial till (Fig. 5).
The authors agree with Professor Sparks that these empirical correlations are no substitute for testing clay. Experience has shown, however, that the 'measles' plot generated from routine tests in glacial tills makes it difficult to select design values. It is likely that a design engineer will err on the conservative side when selecting characteristic values because of the spatial variability of the tills. This can lead to uneconomic design. Hence the empirical correlations provide a framework to help select the characteristic values.

\section{REFERENCES}

Lee, I. K. \& Inglis, O. G. (1968). Strength and deformation of soils and rocks. In Soil mechanics, selected topics (ed. I. K. Lee), chapter 4, pp. 195-294. London: Butterworths.

Skempton A. W. \& Bishop A. W. (1954). Soils. In Building materials, their elasticity and inelasticity (ed. M. Reiner), chapter 10, pp. 417-482. Amsterdam: North-Holland Publishing.

Sparks A. D. W. (1999). A unified theory for clays, for students and practice. Geotechnics for developing Africa. Proc. 12th Reg. Conf. for Africa on Soil Mech. and Geotech. Engng, Durban, 505-514. 